\title{
P02.151. Effect of Ayurvedic treatment in diabetic sensory polyneuropathy: a non-randomized, observational clinical study
}

\author{
P Kalapi $^{1 *}$, M Patel $^{1}$, C Mehta $^{1}$, C Kessler $^{2}$, S Gupta $^{1}$ \\ From International Research Congress on Integrative Medicine and Health 2012 \\ Portland, Oregon, USA. 15-18 May 2012
}

\section{Purpose}

Diabetic sensory neuropathy is a common complication affecting approximately $30 \%$ of patients with diabetes mellitus. Conventional drugs are used for symptomatic relief only and, moreover, have certain side effects. In Ayurveda, various treatment modalities for diabetic sensory polyneuropathy have been described in detail and are being used successfully in routine Ayurvedic care.

\section{Methods}

Thirty-three patients with clinical features of diabetic sensory polyneuropathy confirmed both clinically and with a neuropathy analyzer machine were included. All patients received Ayurvedic treatment as outpatients or inpatients (depending on the severity) for one month. Treatment included oral administration of Phyllanthus niruri powder $3 \mathrm{~g}$ twice a day and Abutilon indicum root decoction $40 \mathrm{ml}$ twice a day. Patients also received Ayurvedic dietary advice (in particular avoidance of spicy, sour, deep fried, hot and refrigerated food items). Patients were assessed for changes in clinical features based on subjective scoring at admission and at the time of completion of the treatment. The neuropathy analyzer machine was used for recording sensory perception of vibration and cold and heat sensations in the feet. Data were analyzed statistically by using the student's t-test.

\section{Results}

All 33 patients completed Ayurvedic treatment. The results showed significant $(\mathrm{p}<0.001)$ relief in numbness (70.2 $\pm 0.7 \%)$, tingling sensations $(72 \pm 0.5 \%)$, burning sensations $(77.6 \pm 0.8 \%)$ and pain in lower limbs $(64 \pm 0.5 \%)$.

1J.S.Ayurved College, Nadiad, Gujarat, India
There were also significant $(\mathrm{p}<0.001)$ improvements in right and left foot sensory perception of vibration $(31.2 \pm 8.7 \%$ and $32.6 \pm 8.7 \%$, respectively), cold sensation $(19.7 \pm 5.1 \%$ and $23.1 \pm 6.4 \%)$ and heat sensation $(6.9 \pm 3.9 \%$ and $5.2 \pm 3.9 \%)$.

\section{Conclusion}

The results of this pilot study point towards a possibly effective and safe Ayurvedic treatment approach for diabetic sensory neuropathy. Larger trials are warranted to support these findings.

\section{Author details}

${ }^{1}$ J.S.Ayurved College, Nadiad, Gujarat, India. ${ }^{2}$ Charité Medical University, Berlin, Germany.

Published: 12 June 2012

\section{doi:10.1186/1472-6882-12-S1-P207}

Cite this article as: Kalapi et al:: P02.151. Effect of Ayurvedic treatment in diabetic sensory polyneuropathy: a non-randomized, observational clinical study. BMC Complementary and Alternative Medicine 2012 12(Suppl 1):P207.

Submit your next manuscript to BioMed Central and take full advantage of:

- Convenient online submission

- Thorough peer review

- No space constraints or color figure charges

- Immediate publication on acceptance

- Inclusion in PubMed, CAS, Scopus and Google Scholar

- Research which is freely available for redistribution
Full list of author information is available at the end of the article

C Biomed Central

(c) 2012 Kalapi et al; licensee BioMed Central Ltd. This is an Open Access article distributed under the terms of the Creative Commons Attribution License (http://creativecommons.org/licenses/by/2.0), which permits unrestricted use, distribution, and reproduction in any medium, provided the original work is properly cited. 